\title{
The newly discovered Churchill kimberlite field, Canada: Petrography, mineral chemistry and geochronology.
}

\author{
S. Zurevinski ${ }^{1}$, L.M. Heaman ${ }^{1}$, R.A. Creaser ${ }^{1}$, and P. Strand ${ }^{2}$ \\ ${ }^{1}$ Department of Earth and Atmospheric Sciences, University of Alberta, Edmonton, Alberta, Canada. \\ ${ }^{2}$ Shear Minerals Ltd., Edmonton, Alberta, Canada.
}

\section{Introduction}

The discovery of the Churchill kimberlite field was announced in 2003 by Shear Minerals Ltd, along with partners Stornoway Diamond Corp and BHP Billiton. The Churchill kimberlite field is located in the Churchill Province cratonic rocks, immediately west of Hudson Bay between the communities of Rankin Inlet and Chesterfield Inlet, Nunavut (Figure 1). Today this project encompasses an area in excess of 2.5 million acres, and 45 kimberlites have been confirmed by drilling.

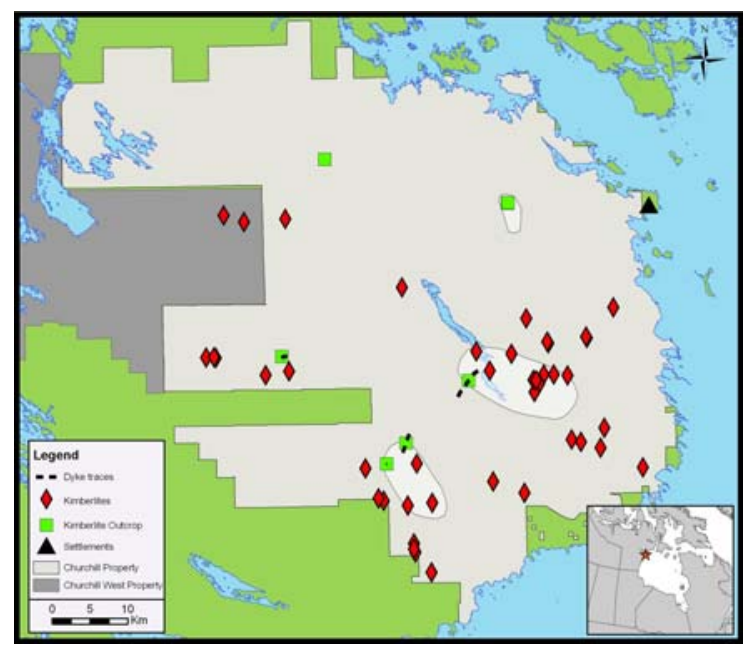

Figure 1. General geologic map of the Churchill kimberlite field, Nunavut.

\section{Mineralogy}

The mineralogy and petrology of 24 kimberlite bodies have been extensively studied in order to better constrain their nature and origin. Petrographic features, matrix mineralogy and mineral chemistry confirm that the majority of Churchill occurrences investigated so far are archetypal or Group I kimberlite. Extreme variation in the primary kimberlite mineralogy exists across the field, ranging from sparsely macrocrystic oxide-rich calcite magmatic kimberlite, to macrocrystic oxide-rich monticellite phlogopite magmatic kimberlite, to a highly evolved serpentine magmatic kimberlite.

Olivine and phlogopite are the dominant macrocrysts. Macrocrystal olivine have a small variation in Fo content from Fo90 to Fo92. Phenocrystal and microphenocrystal olivine have overlapping compositions, providing evidence that macrocrystal olivine crystallized directly from the kimberlite magma.

Groundmass mineralogy mainly consists of olivine, phlogopite, ilmenite, monticellite, perovskite, spinel, primary and secondary calcite, apatite, primary and secondary serpentine, chlorite, and rare accessory minerals such as djerfisherite, zircon and pyrite.

Spinel compositions follow the "magmatic trend 1", otherwise known as the magnesian ulvöspinel trend (Figure 2) after Mitchell and Clarke (1976). Overall the compositional trend across the spinel prism shown in Figure 2 represents a $\mathrm{Fe}$ - and Ti-enrichment, crystallizing TiMACs (Titianium - Magnesium Aluminium Chromites), to MUMs (Magnesian ulvöspinel-Ulvöspinel-Magnetites) to Magnetite. There is a discontinuum in the crystallization sequence of spinels, shown in Figure 2, where there are two distinct compositional groups of spinels representing the initial and the final portions of the spinel crystallization sequence.

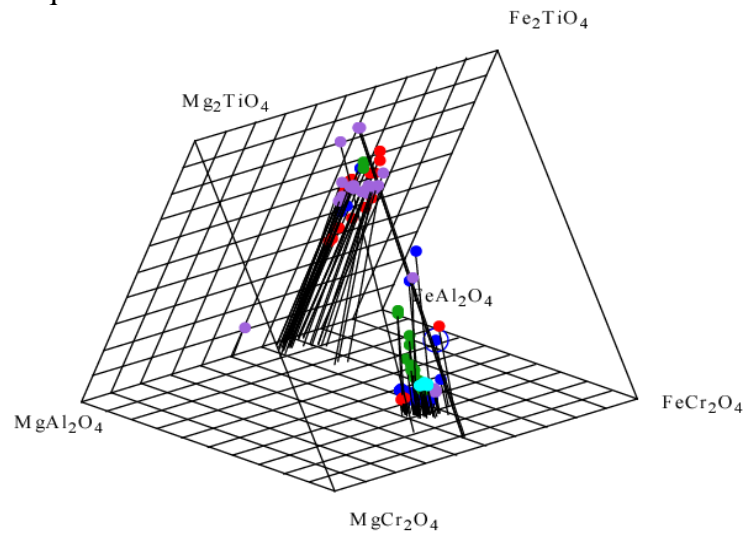

Figure 2. A reduced spinel prism with compositions of Churchill spinels shown representing the magnesian ulvöspinel trend (after Mitchell and Clarke, 1976).

Perovskite Sr Isotopic Composition 
Perovskite fractions were chosen from four kimberlite intrusions emplaced within the Churchill kimberlite field to establish the primary $\mathrm{Sr}$ isotopic composition of these magmas. The results indicate that Churchill kimberlites have initial ${ }^{87} \mathrm{Sr} /{ }^{86} \mathrm{Sr}$ ratios ranging from $0.7032-0.7036$, and generally fall within the range previously reported for kimberlitic perovskite. The ratios are consistent with previous whole rock initial ${ }^{87} \mathrm{Sr} /{ }^{86} \mathrm{Sr}$ ratios from South African Group I kimberlites (0.7033-0.7049) (Smith 1983).

\section{Geochronology}

Twenty seven new high precision U-Pb perovskite and $\mathrm{Rb}-\mathrm{Sr}$ phlogopite ages have been determined for the Churchill kimberlites, indicating that magmatism spans $\sim 45$ million years between 225 and $170 \mathrm{Ma}$. The ages obtained for the Churchill kimberlites are interpreted to record three main pulses of magmatic activity, the first at $\sim 225-219 \mathrm{Ma}$, the second at $\sim 204-181$ and the final at $\sim 175-170 \mathrm{Ma}$ (Figure 3 ). The location and timing of Churchill kimberlite emplacement is consistent with the previously proposed NW-SE trending corridor of Jurassic/Triassic kimberlite magmatism in eastern North America, which includes the Attawapiskat and Kirkland Lake kimberlite fields (Heaman and Kjarsgaard, 2000). The Churchill kimberlites studied here extend this corridor a further $\sim 800 \mathrm{~km} \mathrm{NW}$ and the corridor may continue even further. This corridor is interpreted as the continental expression of magmatism, linked to either a single or multiple mantle plume hotspot track(s). The pattern and location of kimberlite emplacement along this corridor is geographically consistent with independent estimates for the timing and location of the continental extension of both the Great Meteor and Verde hotspot tracks (Figure 4).

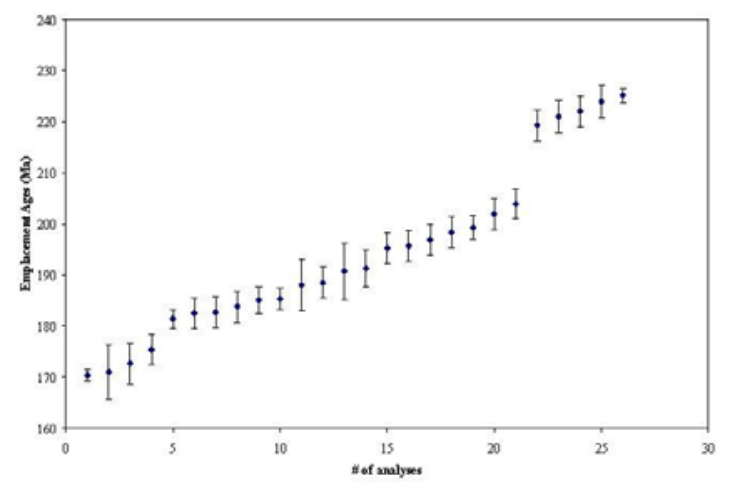

Figure 3. Distribution of Churchill kimberlite emplacement ages based on U-Pb and $\mathrm{Rb}-\mathrm{Sr}$ ages obtained in this study.

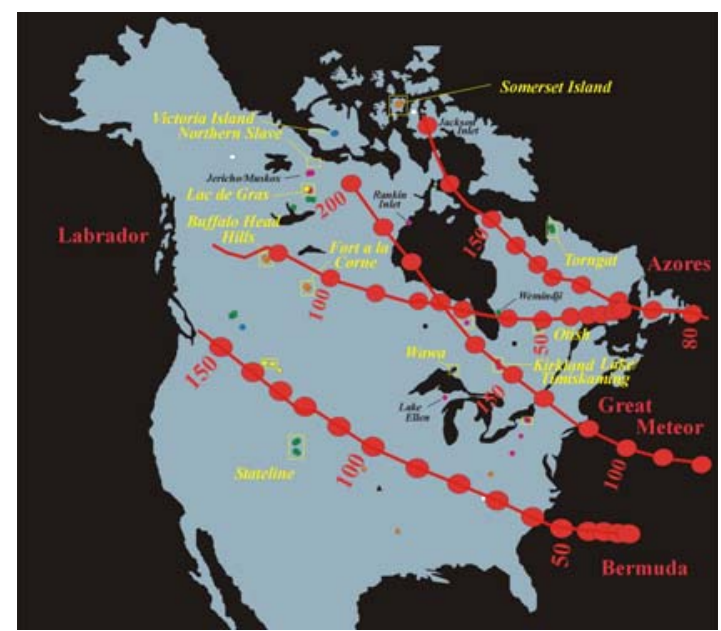

Figure 4. Map of North America that shows the distribution of kimberlite clusters and fields and the continental extensions of four mantle hotspot tracks during the Mesozoic and Cenozoic (from Heaman et al. 2004).

\section{References}

Heaman, L.M. and Kjarsgaard, B.A. 2000. Timing of Eastern North American kimberlite magmatism: continental extension of the Great Meteor Hotspot Track? Earth and Planetary Science Letters, 178: 253268.

Heaman, L.M., Kjarsgaard, B.A and Creaser R.A. 2004. The temporal evolution of North American kimberlites. Lithos, 76: 377-397.

Mitchell, R.H. and Clarke, D.B. 1976. Oxide and sulphide mineralogy of the Peuyuk kimberlite, Somerset Island, N.W.T., Canada. Contributions to Mineralogy and Petrology, 56: 157-172.

Smith, C.B. 1983. Pb, Sr, and Nd isotopic evidence for sources of African Cretaceous kimberlite. Nature, 304: 51-54. 
-

$9^{\text {th }}$ IKC 